\title{
Ethnobotany and traditional medicine of the inhabitants of the Pantanal Negro sub-region and the raizeiros of Miranda and Aquidauna, Mato Grosso do Sul, Brazil
}

\author{
Oliveira, AKM.*, Oliveira, NA., Resende, UM. and Martins, PFRB. \\ Programa de Pós-graduação em Meio Ambiente e Desenvolvimento Regional, Universidade Anhanguera - Uniderp, \\ Rua Alexandre Herculano, 1400, Jardim Veraneio, CEP 79037-280, Campo Grande, MS, Brazil \\ *e-mail: akmorbeck@hotmail.com \\ Received October 14, 2010 - Accepted December 13, 2010 - Distributed April 30, 2011
}

(With 1 figure)

\begin{abstract}
A survey on the use of medical plants was carried out in the rural communities of the Rio Negro sub-region of the Pantanal and the raizeiros from Aquidauana and Miranda municipalities, Mato Grosso do Sul, Brazil, in order to recover the ethnobotanical and ethnopharmacological knowledge of these communities. Structured questionnaires were run with the residents of eight farms and 12 raizeiros. The results reveal 25 botanical families, 45 genera and 48 species of medicinal plants used, six of which are indicated for kidney disturbances, six for urinary disturbances, five for inflammation treatment, 13 for stomach aches, 10 for respiratory disturbances, four for treating sprains, four for healing wounds, four as anti-diarrheaic and one as antipyretic, among other illnesses. The main family was Asteraceae, with 12 species used. The principal preparation methods of the medicinal herbs in the Rio Negro sub-region and surrounding areas were infusion (35) and, mostly, mixed with "chimarrão" or "mate quente", traditional beverage. Nineteen exotic species are used by the raizeiros, (39.58\%), which indicates a strong influence of the urban environment. The traditional pantaneiros have greater knowledge of medicinal plants than the raizeiros, and they cited only five exotic species (16.1\%).
\end{abstract}

Keywords: folk medicine, medicinal plants, ethnopharmacology.

\section{Etnobotânica e medicina tradicional dos habitantes da sub-região do Pantanal do Negro e raizeiros das cidades de Miranda e Aquidauana, Mato Grosso do Sul, Brasil}

\section{Resumo}

Foi realizado um levantamento sobre o uso de plantas medicinais junto às comunidades rurais, da sub-região do Rio Negro e raizeiros das cidades de Aquidauana e Miranda, Mato Grosso do Sul, Brasil. O objetivo foi resgatar o conhecimento etnobotânico e etnofarmacológico dessas comunidades, por meio da aplicação de questionários a moradores de oito fazendas e 12 raizeiros. Os resultados indicaram a utilização de 25 famílias, 45 gêneros e 48 espécies de plantas medicinais, sendo seis utilizadas para afecções dos rins, seis para tratamento das vias urinárias, cinco no tratamento de inflamações, 13 para dores estomacais, quatro como cicatrizantes, 10 para afecções do aparelho respiratório, quatro para todo o tipo de torções, quatro como antidiarreicas e uma no combate às febres, entre outras doenças. A principal família utilizada é Asteraceae, com 12 espécies. As principais formas de utilização das plantas são os chás por infusão (citado 35 vezes), isoladamente ou com as partes da planta misturadas no mate quente ou chimarrão, bebidas tradicionais da região pantaneira. O número de espécies exóticas utilizadas, 19 (39,58\%), indica forte influência das correntes migratórias para a região, o que pode comprometer a médio e longo prazos, o conhecimento das populações locais. Os pantaneiros tradicionais têm maior conhecimento sobre as plantas medicinais nativas do que os raizeiros das cidades de Miranda e Aquidauna, citando apenas cinco espécies exóticas (16,1\%).

Palavras-chave: medicina popular, plantas medicinais, etnofarmacologia. 


\section{Introduction}

The use of plants in the treatment of several diseases is reported in different populations (e.g., Berg and Silva, 1988; Bird, 1991; Verger, 1995; Guarim-Neto, 2006; Kunwar et al., 2006). The knowledge of medicinal plants often represents the only therapeutic option for many communities and ethnic groups. Revene et al. (2008) point out that traditional medicine in poor countries is the most accessible practice and, in certain situations, the only treatment available.

According to Maciel et al. (2002), the use of plants to treat and cure diseases is as old as the human species and today in the poorest regions of the country and even on the outskirts of large Brazilian cities, medicinal plants are sold in street markets and fairs and found in the backyards of residences. The World Health Organization (WHO) states that approximately $80 \%$ of the population use traditional medicine in primary health care (WHO, 2002). The discovery and disclosure of medicinal flora properties, through the knowledge of traditional populations, is, therefore, an important tool in preserving the cultural richness of different regions.

In Brazil, the use of herbs for medicinal purposes is a widespread practice, enhanced by cultural differences, deriving from colonisation by the European and African populations, in addition to traditional indigenous knowledge (Gomes et al., 2008). According to Martins et al. (2000), the use of plants to treat diseases has, fundamentally, influences from several different cultures that include the Indians who use phytotherapy in a mystical way: the shaman or witch doctor of the tribe often uses herbs with narcotic and/or hallucinogenic effects to dream about spirits. These reveal the herb or the procedure to be followed to cure the sick person, or the shaman may observe animals that look for certain plants when they are sick. Black populations descended from African slaves have also introduced new species with curative intent, seeking to "expel" the disease through rituals and natural products, including those of animal origin.

This mixture of traditions, associated with the high plant diversity in Brazil, has led to a traditional medicine based on different plants and methods of treatment and researchers (e.g., such as Correa, 1926-1978; Rizzini and Mors, 1976; Berg, 1993; Ming, 1995; Agra, 1996) demonstrate the richness of medicinal flora in different Brazilian regions.

Among the Brazilian biomes, the Pantanal is a region with associated vegetation formations and, according to Pott and Pott (1994), the colonisation of species from regions like Chaco, Cerrado, Amazon and Atlantic forest has allowed the occurrence of wide distribution species and low endemism. Alho (2008a,b) and Oliveira (2007, 2008) affirm that each sub-region of Pantanal wetland (a periodically flooded area), shows vegetation characteristics associated with different environmental factors such as soil type, flood level and slope, which influence species distribution and provide great floristic diversity.
Thus, this biome is an important vegetation complex for the study of medicinal herbs, covering a diversity of species with great potential for ethnobotanical studies (e.g. Conceição and Paula, 1986; Pott and Pott, 1994; Bortolotto, 1999; Souza and Guarim-Neto, 1999; Pott and Pott, 2000; Schwenk and Silva, 2000; Campos Filho, 2002). It is also occupied by a native population with great cultural importance, adapted to the intermittent cycles of flood and drought of the region, the pantaneiros or marsh-dwellers (Nogueira, 2002).

The use of plants for therapeutic purposes in the Pantanal region has long been reported in various Indian tribes. Since the first colonisation of the region, especially during the Paraguay War (1864-1870), extractivist activities have been intensified in other communities and are now part of the 'pantaneiros' lives, either for medicinal ends or just to bring comfort in the face of their daily adversities (WHO, 2002).

The knowledge of the correct use of plant species normally belongs to restricted groups of the population, known as raizeiros (generally people with little formal education, who through the knowledge transmitted by their parents or other people with empirical knowledge, use plants for disease treatment), benzedeiras (usually women, who treat distinct diseases through prayer and herbs) and other, usually elderly, people, who received medicinal information from their ancestors (Guarim-Neto, 2006). As these groups are restricted and often threatened by environmental changes, which alter their lifestyle and culture, the recovery of this ethnobotanical knowledge is fundamental in rescuing traditions that may soon be lost.

Considering the information gaps in the ethnobotanical and ethnopharmacological knowledge of the traditional pantaneiros from Rio Negro sub-region and the raizeiros of the municipalities of Aquidauana and Miranda, this work aims to identify the plants used in folk medicine and their respective utilisation.

\section{Material and Methods}

This study was conducted with 14 traditional residents of eight farms (Santa Emilia, Chão Parado, Conquista, Santa Maria, Campo Lourdes, São Roque, Bandeirantes and Santa Marta) near the city of Aquidauana, and with twelve raizeiros, six from the urban area of Aquidauana and six of Miranda municipalities, located at the edge of the southern Pantanal, Mato Grosso do Sul, Brazil (Figure 1).

These towns are directly influenced by the Pantanal region. They have a large rural-origin population and, for this reason, were chosen to be the interview set.

A structured questionnaire (popular name, preparation method and therapeutic indications) was developed and applied in march-october/2008, in order to define a profile of the traditional pantaneiros and raizeiros, concerning their experience and knowledge of the therapeutic usage of medicinal plants. The species cited by Sano and Almeida (1998) and Pott and Pott $(1994,1999)$ were considered 


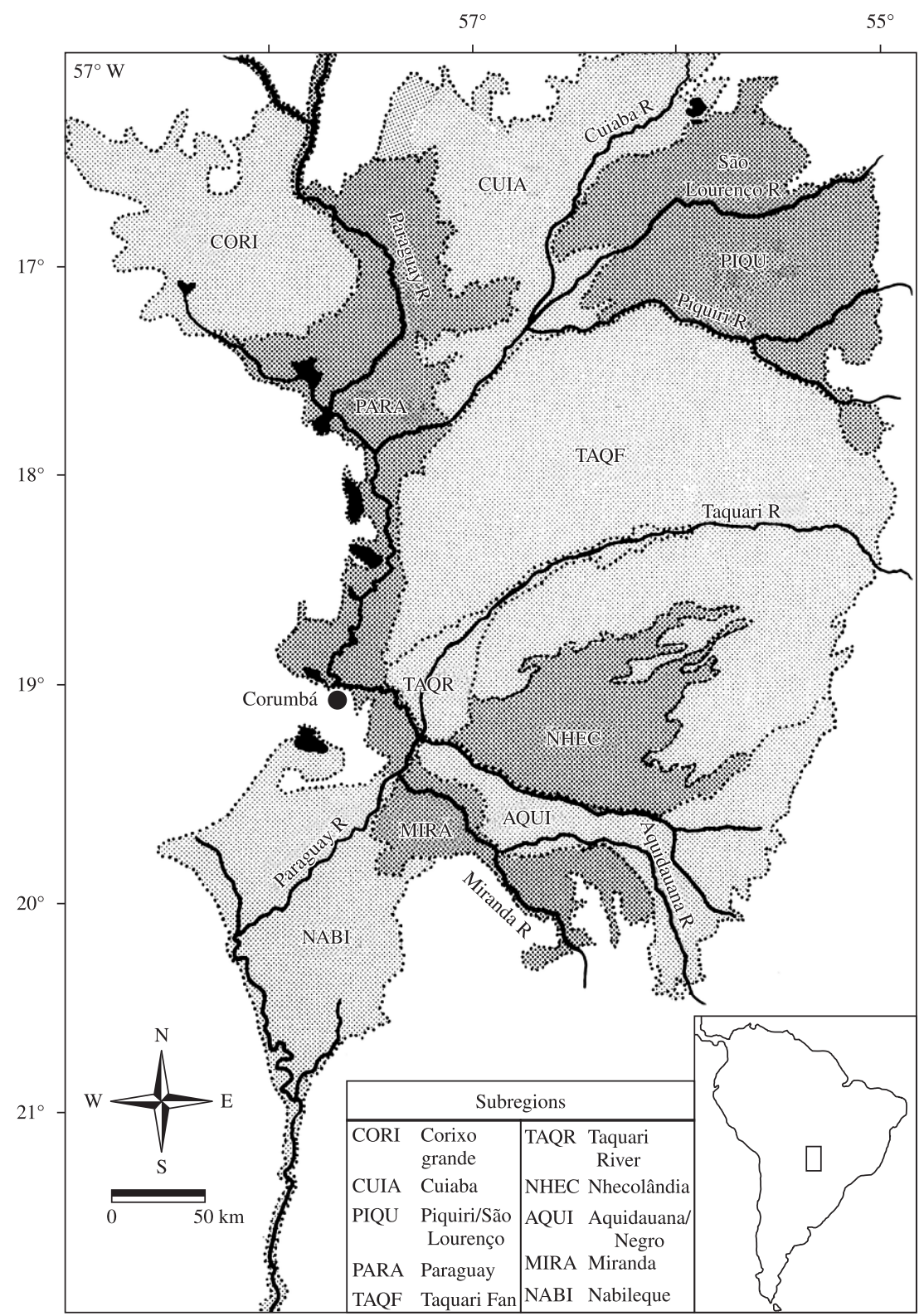

Figure 1. Map of the Pantanal wetland, showing the 10 subregions, by Hamilton et al. (1996).

native to the region, and Lorenzi and Matos (2002) were also consulted.

In this study, the interviews were designed for people born in the Pantanal region or who have spent most of their lives in the region, and interacted with the environment through the use of natural resources as a way of survival. To avoid embarrassment, the interviewees were free to speak according to their own situation and the interviews were carried out using regional language.

The species mentioned by the pantaneiros and raizeiros were collected in the indicated areas by the interviewees, and transported to the Anhanguera-Uniderp University herbarium for identification and deposit. The classification system used was APG II (Angiosperm Phylogeny Group, 2003).

\section{Results and Discussion}

In the present study 25 families, 45 genera and 48 species of medicinal plants of routine use were identified, 19 of which were exotic species (introduced in the region) and $29(60.42 \%)$ were native (Table 1$)$. The family with largest number of used species was Asteraceae (12), followed by the family Lamiaceae (7).

The herb "boldo" (P. barbatus), an introduced species, was the most cited (seven times), which indicates the strong 
Table 1. Family, popular and scientific name, citation number $(\mathrm{CN})$ - "Pantaneiros" $(\mathrm{P})$ and "raizeiros" (R), preparation method (PM), therapeutic indications (TI) and origin of the medicinal plants cited by the raizeiros of the municipalities of Aquidauana and Miranda and by the traditional pantaneiros of the Rio Negro sub-region, Pantanal, Mato Grosso do Sul, Brazil.

\begin{tabular}{|c|c|c|c|c|c|}
\hline Family & Popular and scientific name & $\mathrm{CN}$ & PM & TI & $\begin{array}{l}\text { Native } \\
\text { species }\end{array}$ \\
\hline Adoxaceae & $\begin{array}{l}\text { Sabugueiro - Sambucus australis } \\
\text { Cham. \& Schltdl. }\end{array}$ & $1-\mathrm{P}$ & Infusion & Measles and fever & Yes \\
\hline \multirow[t]{2}{*}{ Amaranthaceae } & $\begin{array}{l}\text { Terramicina, Chapéu de couro } \\
\text { (Cabeça-branca), Estomalina - } \\
\text { Alternanthera brasiliana (L.) O. } \\
\text { Kuntze }\end{array}$ & $\begin{array}{l}1-\mathrm{R} \\
1-\mathrm{P}\end{array}$ & $\begin{array}{l}\text { Poultice (2) } \\
\text { Infusion (1) }\end{array}$ & $\begin{array}{c}\text { Wounds (2) } \\
\text { Stomach aches (1) }\end{array}$ & Yes \\
\hline & $\begin{array}{l}\text { Erva-de-Santa Maria ou mastruz - } \\
\text { Chenopodium ambrosioides L. }\end{array}$ & $\begin{array}{l}3-\mathrm{R} \\
2-\mathrm{P}\end{array}$ & Smoothie & Vermifuge & Yes \\
\hline Arecaceae & Coco da Bahia - Cocos nucifera L. & $\mathrm{R}-1$ & Infusion & Hepatitis & No \\
\hline \multirow[t]{11}{*}{ Asteraceae } & $\begin{array}{l}\text { Anador - Artemisia verlotorum } \\
\text { Lamotte }\end{array}$ & $\begin{array}{l}2-\mathrm{R} \\
2-\mathrm{P}\end{array}$ & Infusion & Pains & Yes \\
\hline & $\begin{array}{l}\text { Chifre-de-carneiro - } \\
\text { Acanthospermum hispidum DC. }\end{array}$ & $\begin{array}{l}1-\mathrm{R} \\
1-\mathrm{P}\end{array}$ & Infusion & $\begin{array}{l}\text { Diuretic/ } \\
\text { kidney disturbances }\end{array}$ & Yes \\
\hline & Picão - Bidens pilosa L. & $\begin{array}{l}2-\mathrm{R} \\
1-\mathrm{P}\end{array}$ & Infusion & Verminosis & Yes \\
\hline & $\begin{array}{l}\text { Arnica - Lychnophora ericoides } \\
\text { Mart. }\end{array}$ & $\begin{array}{l}2-\mathrm{R} \\
1-\mathrm{P}\end{array}$ & Poultice & $\begin{array}{l}\text { Healing/ } \\
\text { Pains }\end{array}$ & Yes \\
\hline & $\begin{array}{l}\text { Caferana - Vernonia polyanthes } \\
\text { Less. }\end{array}$ & $1-\mathrm{P}$ & Infusion & Stomach aches & Yes \\
\hline & $\begin{array}{l}\text { Guaco - Mikania laevigata Schultz } \\
\text { Bip. ex Baker }\end{array}$ & $1-\mathrm{R}$ & Infusion & Cough & Yes \\
\hline & $\begin{array}{l}\text { Camomila - Chamomilla recutita } \\
\text { (L.) Rauschter }\end{array}$ & $1-\mathrm{R}$ & Infusion & Colic and sedative & No \\
\hline & $\begin{array}{l}\text { Cravo-de-defunto - Tagetes patula } \\
\text { L. }\end{array}$ & $1-\mathrm{R}$ & Infusion & Pneumonia & No \\
\hline & $\begin{array}{l}\text { Carqueja - Baccharis articulata } \\
\text { (Lam.) Pers. }\end{array}$ & $1-\mathrm{R}$ & Infusion & Stomach aches & Yes \\
\hline & $\begin{array}{l}\text { Assa-peixe - Vernonia ferruginea } \\
\text { Less. }\end{array}$ & $1-\mathrm{P}$ & Infusion & $\begin{array}{l}\text { Cough/ } \\
\text { Snoring }\end{array}$ & Yes \\
\hline & $\begin{array}{l}\text { Erva de Luceira - Pluchea sagittalis } \\
\text { ( Lam.) Cabrera }\end{array}$ & $\begin{array}{l}2-\mathrm{R} \\
1-\mathrm{P}\end{array}$ & Poultice & $\begin{array}{l}\text { Wounds/ } \\
\text { Sprains }\end{array}$ & Yes \\
\hline \multirow[t]{2}{*}{ Bignoniaceae } & $\begin{array}{l}\text { Piúva - Tabebuia heptaphylla (Vell.) } \\
\text { Tol. }\end{array}$ & $1-\mathrm{P}$ & Infusion & Inflammation & Yes \\
\hline & $\begin{array}{l}\text { Paratudo, Ipê - T. aurea (Manso) } \\
\text { Benth. \& Hook. f. ex. S. Moore }\end{array}$ & $\begin{array}{l}1-\mathrm{R} \\
2-\mathrm{P}\end{array}$ & $\begin{array}{l}\text { Decoction (1) } \\
\text { Infusion (2) }\end{array}$ & $\begin{array}{c}\text { Bronchitis/ } \\
\text { Inflammationand } \\
\text { several different } \\
\text { ailments } \\
\text { Stomach }\end{array}$ & Yes \\
\hline Celastraceae & $\begin{array}{l}\text { Cancorosa - Maytenus cf. } \\
\text { macrodonta Reiss. }\end{array}$ & $1-\mathrm{P}$ & Infusion & Infection & Yes \\
\hline Crassulaceae & $\begin{array}{l}\text { Saião - Kalanchoe brasiliensis } \\
\text { Camb. }\end{array}$ & $1-\mathrm{P}$ & Chew the leaf & Stomach aches & No \\
\hline Curcubitaceae & $\begin{array}{l}\text { Melão-de-São-Caetano - Momordica } \\
\text { charantia L. }\end{array}$ & $1-\mathrm{P}$ & Poultice & Healing & No \\
\hline Euphorbiaceae & $\begin{array}{l}\text { Quebra-pedra - Phyllanthus amarus } \\
\text { K. Schum. }\end{array}$ & $\begin{array}{l}1-\mathrm{R} \\
2-\mathrm{P}\end{array}$ & Infusion & Kidney stones & Yes \\
\hline
\end{tabular}


Table1. Continued...

\begin{tabular}{|c|c|c|c|c|c|}
\hline Family & Popular and scientific name & $\mathbf{C N}$ & PM & TI & $\begin{array}{l}\text { Native } \\
\text { species }\end{array}$ \\
\hline \multirow[t]{2}{*}{ Fabaceae } & $\begin{array}{l}\text { Fedegoso - Senna occidentalis (L.) } \\
\text { Link }\end{array}$ & $\begin{array}{l}1-\mathrm{R} \\
3-\mathrm{P}\end{array}$ & Cold tea & $\begin{array}{l}\text { Stimulant/ } \\
\text { Verminosis }\end{array}$ & Yes \\
\hline & $\begin{array}{l}\text { Amargoso - Vatairea macrocarpa } \\
\text { (Benth.) Ducke. }\end{array}$ & $1-\mathrm{P}$ & Infusion & $\begin{array}{l}\text { Stomach/ } \\
\text { Liver }\end{array}$ & Yes \\
\hline \multirow[t]{7}{*}{ Lamiaceae } & Boldo - Plectranthus barbatus Andr. & $\begin{array}{l}4-\mathrm{R} \\
3-\mathrm{P}\end{array}$ & $\begin{array}{l}\text { Maceration/ } \\
\text { Cold tea }\end{array}$ & Digestion & No \\
\hline & $\begin{array}{l}\text { Boldo (Boldo do Chile) - } \\
\text { P. neochilus Schlechter }\end{array}$ & $1-\mathrm{P}$ & Infusion & $\begin{array}{l}\text { Head and stomach } \\
\text { aches }\end{array}$ & No \\
\hline & Erva cidreira - Melissa officinalis L. & $\begin{array}{l}2-\mathrm{R} \\
1-\mathrm{P}\end{array}$ & Infusion & $\begin{array}{l}\text { High pressure and } \\
\text { insomnia }\end{array}$ & No \\
\hline & Poejo - Mentha pulegium L. & $2-\mathrm{R}$ & Infusion & Flu & No \\
\hline & $\begin{array}{l}\text { Hortelã do campo - Hyptis crenata } \\
\text { Pohl ex Benth. }\end{array}$ & $1-\mathrm{R}$ & Infusion & Vermifuge & Yes \\
\hline & Alecrim - Rosmarinus officinalis L. & $2-\mathrm{R}$ & Infusion & Heart disturbances & No \\
\hline & Hortelã gorda - Mentha x piperita L. & $1-\mathrm{P}$ & Infusion & Stomach aches & No \\
\hline Lauraceae & Abacateiro - Persea americana Mill. & $1-\mathrm{R}$ & Infusion & Urinary disturbances & No \\
\hline Lytraceae & Romã - Punica granatum L. & $1-\mathrm{R}$ & Infusion & Gastritis & No \\
\hline Malvaceae & $\begin{array}{l}\text { Malva branca - Waltheria communis } \\
\text { A. St.-Hil. }\end{array}$ & $2-\mathrm{P}$ & Infusion & Wound asepsis & Yes \\
\hline Nyctaginaceae & Amarra-pinto - Boerhavia diffusa L. & $1-\mathrm{R}$ & Infusion & $\begin{array}{l}\text { Infection/ } \\
\text { Diuretic }\end{array}$ & Yes \\
\hline Piperaceae & $\begin{array}{l}\text { Pariparoba - Piper regnellii (Miq) } \\
\text { C. DC. }\end{array}$ & $2-\mathrm{P}$ & Infusion & Stomach & Yes \\
\hline Plantaginaceae & $\begin{array}{l}\text { Vassourinha - Scoparia } \\
\text { montevidensis (Spreng.) R. E. Fries }\end{array}$ & $2-\mathrm{P}$ & Infusion & Renal pains & Yes \\
\hline \multirow[t]{2}{*}{ Poaceae } & $\begin{array}{l}\text { Capim amargoso - Setaria } \\
\text { poiretiana (Schult.) Kunth. }\end{array}$ & $1-\mathrm{P}$ & Poultice & Healing & Yes \\
\hline & $\begin{array}{l}\text { Capim cidreira - Cymbopogon } \\
\text { citratus (D.C.) Stapf }\end{array}$ & $\begin{array}{l}1-\mathrm{R} \\
1-\mathrm{P}\end{array}$ & Infusion & Sedative & No \\
\hline Polygonaceae & $\begin{array}{l}\text { Erva-de-bicho - Polygonum } \\
\text { hydropiperoides Michx. }\end{array}$ & $1-\mathrm{P}$ & Poultice & $\begin{array}{l}\text { Wound asepsis/ } \\
\text { Chilblain }\end{array}$ & Yes \\
\hline Rubiaceae & $\begin{array}{l}\text { Congonha de bugre - Rudgea } \\
\text { viburnoides (Cham.) Benth. }\end{array}$ & $2-P$ & Infusion & $\begin{array}{l}\text { Heart disturbances/ } \\
\text { kidney }\end{array}$ & Yes \\
\hline \multirow[t]{2}{*}{ Rutaceae } & Arruda - Ruta graveolens L. & $1-\mathrm{R}$ & Infusion & Menstrual colic pains & No \\
\hline & $\begin{array}{l}\text { Laranjeira - Citrus aurantium var. } \\
\text { Dalmau }\end{array}$ & $1-\mathrm{R}$ & Infusion & Pains/ flu & No \\
\hline \multirow[t]{3}{*}{ Solanaceae } & Beladona - Atropa belladonna L. & $1-\mathrm{R}$ & Hot Poultice & Twist pains & No \\
\hline & Juá - Solanum viarum Dun. & $\begin{array}{l}1-\mathrm{R} \\
2-\mathrm{P}\end{array}$ & Infusion & Kidney & Yes \\
\hline & $\begin{array}{l}\text { Tomate cereja - Solanum } \\
\text { lycopersicon } \mathrm{L} \text {. }\end{array}$ & $1-\mathrm{R}$ & $\begin{array}{l}\text { Maceration/ } \\
\text { Cold Tea }\end{array}$ & Kidney disturbances & No \\
\hline Teophrastaceae & $\begin{array}{l}\text { Erva de bugre - Clavija nutans } \\
\text { (Vell.) Stahl. }\end{array}$ & $1-\mathrm{P}$ & Infusion & Flu & Yes \\
\hline Verbenaceae & $\begin{array}{l}\text { Gervão - Stachytarpheta } \\
\text { cayennensis (Rich.) Vahl }\end{array}$ & $\begin{array}{l}1-\mathrm{R} \\
1-\mathrm{P}\end{array}$ & Ointment & Healing & Yes \\
\hline Xanthorrhoeaceae & Babosa - Aloe arborescens Mill. & $1-\mathrm{R}$ & Hot poultice & Pneumonia & No \\
\hline
\end{tabular}


influence of exotic species on the local culture. Successively, the most remembered herbs were "erva-de-santa Maria" or "mastruz" (C. ambrosioides) (5), "anador" (A. vermolotorum) and "fedegoso" (S. occidentalis) (4), "juá" (S. viarum), "picão" (B. pilosa), "arnica" (L. ericoides), "quebra-pedra" (P. amarus) and "erva cidreira" (M. officinalis) (3).

Most of the interviewees (35-71.4\%) carry out infusion preparations with the herbs, pouring hot water over selected parts of them and letting them steep for a few minutes. The medicinal herbs can be also added to "chimarrão" or "mate-quente", a traditional hot beverage prepared from steeping dried leaves of Ilex paraguariensis A. St.-Hil. This hot beverage is normally drunk when neighbours or friends gather in the early morning or late afternoon to talk about daily issues, forming a particular social setting known as "rodas de prosa".

The latter method is commonly used by the population, due to easy handling of the medicinal plants, uniting the traditional habit of drinking "chimarrão" with the necessity of treating the sick.

The use of medicinal herbs in the states of Mato Grosso and Mato Grosso do Sul is reported by different researchers. Berg (1980) conducted a study in the cities of Cuiabá and Chapada dos Guimarães, Mato Grosso, and reported 103 species used for medicinal purposes. Guarim-Neto (2006), in a compilation of his earlier research, reveals that 56 medicinal plants are used in the traditional medicine practices of pantaneiros, eight more than those reported for the Rio Negro sub-region.

Berg and Silva (1988) performed a survey in the cities of Campo Grande, Aquidauana and Miranda, and in the Pantanal of Mato Grosso do Sul State, in which they listed 104 species considered as medicinal flora. Compared with the data obtained in the present study, 41 species identified in this research were not reported by Berg and Silva (1988).

The Aquidauana and Miranda raizeiros named 33 species, 16 of them exotic (Table 1), such as "abacateiro" ( $P$. americana), "boldo" ( $P$. barbatus), "erva cidreira" (M. officinalis), "erva-de-Santa Maria" (C. ambrosioides), "picão" (B. pilosa), "romã" (P. granatum), among others.

The information obtained indicates that raizeiros interviewed are former residents of rural areas, who moved to the towns to seek a better life. However, they still keep up rural customs, cultivating herbs in the backyard, even when living close to pharmacies. These recent urban residents utilise natural medicine routinely, and share their vast knowledge of medicinal herbs with neighbours and close relatives. However, it was observed that the longer they had lived in the town, the greater was the difficulty to list a significant number of species that had been used in their previous rural life.

Furthermore, $39.58 \%$ of the species mentioned by the raizeiros are exotic, which indicates the strong influence of the urban environment on the utilisation of medicinal flora and the gradual loss of any connection with the rural environment and its medicinal species. The exotic species "boldo" (P. barbatus) was the most mentioned; this species is indicated for stomach aches and as digestive stimulant, similar results found by Guarim-Neto (1984) and Berg (1980). According to Costa et al. (2003), studies revealed that "boldo" has hypotensive, vasodilation, gastric hyposecretory, blood pressure reducing anti-dyspeptic properties. The second most cited species was "erva-de-Santa Maria" (C. ambrosioides) (native), used as a vermifuge. The medicinal use of this species is widespread, showing stomachic, anti-rheumatic and anthelmintic properties. "Alecrim" ( $R$. officinalis), "anador" (A. vermolotorum), "arnica" (L. ericoides), "capim cidreira” (C. citratus), "picão" (B. pilosa) and "poejo" (M. pulegium) were mentioned three times; they are all commonly used in folk medicine, except for "arnica" (Lorenzi and Matos, 2002). The others species were cited only once.

Regarding the answers of traditional pantaneiros, 31 medicinal species were cited (Table 1), with only five exotic ones $(16.1 \%)$, indicating a strong link with the local flora and little external influence on medicinal herb use.

"Boldo" also shows a higher frequency of citations (three), together with "fedegoso" (S. occidentalis), used in phytotherapy as a stimulant, vermifuge and against anemia. The literature demonstrates that organic extracts of $S$. occidentalis have purgative, hepatic, antibacterial, antipyretic, antitumor, expectorant, anti-inflammatory, diuretic, antifungal and neurotoxic properties for cattle (Viegas et al., 2006). The species with only two citations were "anador" (A. vermolotorum), "congonha de bugre" (R. viburnoides), "erva-de-Santa Maria" (C. ambrosioides), "juá" (S. viarum), "malva branca" (W. communis), "paratudo" (T. aurea), "pariparoba" (P. regnellii), "quebra-pedra" (P. amarus) and "vassourinha" (S. montevidensis), commonly used in Brazilian folk medicine (Lorenzi and Matos, 2002; Guarim-Neto, 2006).

There are 13 species common to both localities, such as "anador" (A. vermolotorum), "arnica" (L. ericoides), "boldo" ( $P$. barbatus), "capim cidreira" ( $C$. citratus), "juá" (S. viarum), "picão" (B. pilosa) and others, with the smallest portion of exotic species (4-30.8\%). The traditional pantaneiros apparently have a greater knowledge of native medicinal plants than the raizeiros (residents of urban areas), who mentioned a representative number of exotic plants.

The knowledge of native plants is getting lost in the Pantanal region, due to neglect of the 'pantaneiros' traditional values, their migration to urban areas and contact with new immigrants arriving in the region. The recovery of this empirical knowledge is important for biodiversity conservation, to create alternatives for subsistence livelihoods and to maintain cultural diversity.

Acknowledgements - We are indebted to Anhanguera-Uniderp University, which supported this work (Interdisciplinary Group of Research - GIP Project) and provided a scholarship. And also to the referees, for their anonymous work of corrections and suggestions. 


\section{References}

AGRA, MF., 1996. Plantas da medicina popular dos Cariris Velhos (Paraíba, Brasil): espécies mais comuns. João Pessoa: União. 112 p.

ALHO, CJR., 2008a. Biodiversity of the Pantanal: response to seasonal flooding regime and to environmental degradation. Brazilian Journal of Biology, vol. 68, no. 4, p. 957-966.

-, 2008b. The value of biodiversity. Brazilian Journal of Biology, vol. 68, no. 4, p. 1115-1118.

Angiosperm Phylogeny Group - APG II, 2003. An update of the angiosperm phylogeny group classification of the orders and families of flowering plants: APGII. Botanical Journal of the Linnean Society, vol. 141, no. 4, p. 399-436.

BERG, ME van den., 1980. Contribuição à flora medicinal do Estado de Mato Grosso. Ciência e Cultura, vol. 33, p. 163-170. Suplemento.

BERG, ME. van den and SILVA, MHL., 1988. Contribuição à flora medicinal de Mato Grosso do Sul. Acta Amazonica, vol. 18, no. 1-2, p. 9-22. Suplemento.

-, 1993. Plantas medicinais da Amazônia: contribuição ao seu conhecimento sistemático. Belém: CNPq/MPEG. 206 p.

BIRD, C., 1991. Medicines from the rainforest. New Scientist, vol. 17, p. 34-39.

BORTOLOTTO, IM., 1999. Educação e uso de recursos naturais: um estudo na comunidade de Albuquerque, Corumbá, Mato Grosso do Sul, Pantanal. Cuiabá: Universidade Federal de Mato Grosso. Dissertação de mestrado.

CAMPOS FILHO, LVS., 2002. Tradição e ruptura: cultura e ambiente pantaneiros. Cuiabá: Entrelinhas, 180 p.

CONCEIÇÃO, CA. and PAULA, JE., 1986. Contribuição para o conhecimento da flora do Pantanal mato-grossense e sua relação com a fauna e o homem. In Anais do I Simpósio sobre Recursos Naturais e Sócio-Econômicos do Pantanal, Corumbá. Brasília: Embrapa DDT. p. 107-130.

CORRÊA, MP. 1926-1978. Dicionário das plantas úteis do Brasil e exóticas cultivadas. Rio de Janeiro: Ministério da Agricultura, Indústria e Comércio. 6 volumes.

COSTA, MCCD., AGUIAR, JS. and NASCIMENTO, SC., 2003. Atividade citotóxica de Plectranthus barbatus. Acta Farmacéutica Bonaerense, vol. 22, no. 2, p. 155-158.

GOMES, HHS., DANTAS, IC. and CATÃO, MHCV. 2008. Plantas medicinais: sua utilização nos terreiros de umbanda e candoblé na zona leste de cidade de Campina Grande-Pb. BioFar, vol. 3, no. 1, p. 110-129.

GUARIM-NETO, G. 1984. Plantas utilizadas na medicina popular cuiabana - um estudo preliminar. Revista da Universidade Federal de Mato Grosso, vol. 4, no. 1, p. 45-50.

GUARIM-NETO, G., 2006. O saber tradicional pantaneiro: as plantas medicinais e a educação ambiental. Revista Eletrônica do Mestrado em Educação Ambiental, v. 17, p. 71-89.

HAMILTON, SK., SIPPEL SJ. and MELACK, JM., 1996. Inundation patterns in the Pantanal wetland of South America determined from passive microwave remote sensing. Archiv für Hydrobiologie, vol. 137, no. 1, p. 1-23.

KUNWAR, RM., NEPAL, BK., KSHHETRI, HB., RAI, SK. and BUSSMANN, RW., 2006. Ethnomedicine in Himalaya: a case study from Dolpa, Humla, Jumla and Mustang districts of Nepal. Journal of Ethnobiology and Ethnomedicine, vol. 2, no. 27, 6 p.

LORENZI, H. and MATOS, FJA., 2002. Plantas medicinais no Brasil: nativas e exóticas. Nova Odessa: Instituto Plantarum. 512 p.

MACIEL, MAM., PINTO, AC. and VEIGA JUNIOR, VF., 2002. Plantas medicinais: a necessidade de estudos multidisciplinares. Química Nova, vol. 25, no. 3, p. 429-438.

MARTINS, ER., CASTRO, DM., CASTELLANI, DC. and DIAS, JE., 2000. Plantas medicinais. Viçosa: Editora Universidade Federal de Viçosa. 220 p.

MING, LC., 1995. Levantamento de plantas medicinais na Reserva Extrativista "Chico Mendes" - Acre. Botucatu: Universidade Estadual de São Paulo. Tese de Doutorado.

NOGUEIRA, AX., 2002. Pantanal: homem e cultura. Campo Grande: UFMS. 156 p.

OLIVEIRA, AKM., 2007. Pantanal - alguns parâmetros físicoquímicos e biológicos. In BARBOSA, LM. and SANTOS JUNIOR, NA., Ed. A botânica no Brasil: pesquisa, ensino e políticas públicas ambientais. São Paulo: Sociedade Botânica do Brasil. p. 263-266.

-, 2008. Pantanal - origens e características gerais. In OLIVEIRA, AKM., GARNÉS, SJA. and FAVERO, S., Ed. Meio ambiente e produção interdisciplinar: sociedade, natureza e desenvolvimento. Campo Grande: Uniderp, p. 11-25.

POTT, A. and POTT, VJ., 1994. Plantas do pantanal. Brasília: EMBRAPA, 320 p.

-, 1999. Flora do Pantanal - listagem atual de fanerógamas. In Anais do Simpósio sobre Recursos Naturais e Sócio-Econômicos do Pantanal, Manejo e Conservação, 2, 1996. Corumbá: Embrapa Pantanal. p. 297-325.

POTT, VJ. and POTT, A., 2000. Plantas aquáticas do Pantanal. Brasília: Embrapa Comunicação para Transferência de Tecnologia. 404 p.

REVENE, Z., BUSSMANN, RW. and SHARON, D., 2008. From Sierra to Coast: Tracing the supply of medicinal plants in Northern Peru - A plant collector's tale. Ethnobotany Research \& Applications, vol. 6, p. 15-22.

RIZZINI, CT. and MORS, WB., 1976. Botânica econômica brasileira. São Paulo: EPU/EDUSP. 207 p.

SANO, SM. and ALMEIDA, SM., 1998. Cerrado: ambiente e flora. Planaltina: Embrapa-CPAC. 556 p.

SCHWENK, LM. and SILVA, CJ., 2000. A etnobotânica da morraria Mimoso no Pantanal de Mato Grosso. In Anais do III Simpósio sobre Recursos Naturais e Sócio-Econômicos do Pantanal - Os desafios do novo milênio. Corumbá: Embrapa. p. 1-7.

SOUZA, LF. and GUARIM-NETO, G., 1999. Estudo etnobotânico em duas comunidades ribeirinhas: Coxipó do Ouro e São Gonçalo - MT - Brasil. In Anais do II Simpósio sobre Recursos Naturais e Sócio-Econômicos do Pantanal. Corumbá: Embrapa. p. 471-478.

VERGER, PF., 1995. Ewê: o uso das planas medicinais na sociedade Iorubá. São Paulo: Companhia das Letras. 762 p.

VIEGAS JUNIOR, C., REZENDE, A., SILVA, DHS., CASTROGAMBÔA, I. and BOLZANI, VS., 2006. Aspectos químicos, biológicos e etnofarmacológicos do Gênero Cassia. Química Nova, vol. 29, no. 6, p. 1279-1286.

World Health Organization - WHO, 2002. WHO Traditional Medicine Strategy 2002-2005. Geneva: World Health Organization. 74 p. 